\title{
Generation Y: The Perspective of the Next Generation.
}

\author{
Authors: S C Chukwujindu-Anyanwu, ${ }^{1} \mathrm{O} \mathrm{U}$ Anyanwu. ${ }^{2}$ \\ ${ }^{I}$ Graceland College Enugu.Junior Secondary School.Class 3. Enugu State, Nigeria \\ ${ }^{2}$ Federal Teaching Hospital Abakaliki, Department Of Paediatrics.Ebonyi State, Nigeria.
}

\section{Introduction}

Generations emerge with distinct characteristics. They develop from a number of factors including:

- unique attitudes and circumstances of the times;

- major events such as wars;

- social movements;

- scientific or technological breakthroughs;

- and the social/biological roles of the generation at the time.

\section{Generation Y Early Years}

The Y generation are also called the millennial generation. They are people born between 1977 and 1998. They were born at the time of scientific and technological breakthroughs such us internet and social media, telemedicine etc. Their early years were masked by uncertainty brought about by significant events such as that of threats of terrorism, and global economic recession. There were also outbreak of diseases globaly during their early years.

\section{Characteristics}

This generation have been however raised by overprotective parents known as the boomer parents who told them they were special simply because they were who they were. The coming of the internet and technology made the world closer and things were faster. There was proliferation of fast food restaurants and use of microwave ovens which seemed to make life easier and things generally faster. The Y generation isn't deficient they are simply different. They always want quick fixes and are often impatient. They are creative and thrive better in a flexible workplace. They are multi taskers and prefer to work with hands-on.

\section{Their Belief And Future}

They are great risk takers and enjoy trial and error. Encouraged by community service programs in public schools, Gen Yers have been raised with a civic-minded consciousness. They believe that it is their duty to improve their communities and do good deeds in the areas of race and gender relations, the environment, faith, and politics. If they continue to be motivated by civic duty, and defined by their cosmopolitan outlook and optimism, perhaps they will embrace a world-saving role in the future.

\section{The Generation Y Woman}

Today's Gen Y women are socially confident, conscientious, positive and ambitious. They top the charts across all generations and genders when it comes to altruism and helpfulness, and have a strong focus on people. They are a generation of women well placed to succeed in highly connected, digital workplaces. This is because they're more socially responsive, and their superior people orientation and curiosity see them taking to social media and technology with gusto.The versatility of these women make them combine responsibilities at home with the pursuit of excellent careers yet they make a success of all.They live with and on the internet and are driven by the search for success and a career but at the same time by a refusal to sacrifice personal life to achieve them

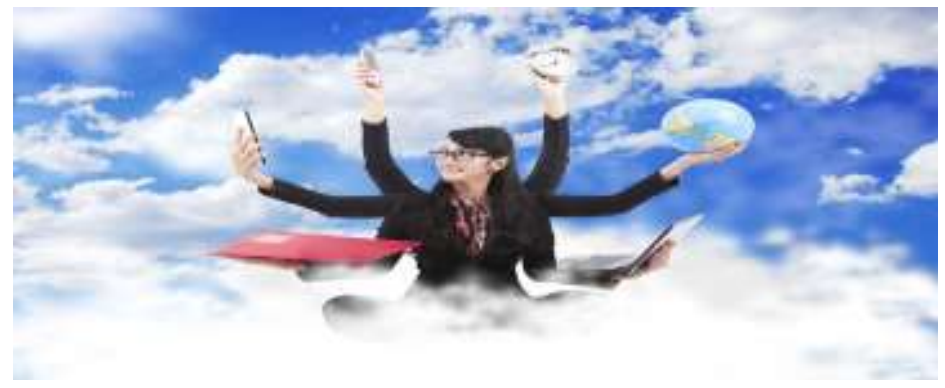




\section{Conclusion}

There is yet another generation the generation $\mathrm{Z}$ still in their infantile stage of which I am one. This generation will be raised by the Generation Y. The success of generation Y will be seen in the next generation.

\section{References}

[1]. Scholz C. Generation Y and Blood Donation: The Impact of Altruistic Help in a Darwiportunistic Scenario. Transfus Med Hemother 2010; 37(4): 195-202.

[2]. Eckleberry-Hunt J, Tucciarone J. The Challenges and Opportunities of Teaching "Generation Y". J Grad Med Educ 2011; 3(4): 458-461.

[3]. Lester H. Generation Y. Br J Gen Pract. 2011; 61(590): 577

[4]. Gardner SF. Preparing for the Nexters. Am J Pharm Educ 2006; 70(4): 87 